\title{
Sosyal Sürdürülebilirlik Performansının Kalıcı Afet Konutlarında Değerlendirilmesi: Bingöl Örneği
}

\author{
Fatma Kürüm Varolgüneş ${ }^{1}$ \\ ORCID: 0000-0002-3214-4274
}

Öz

Afet sonrası kalıcı konut uygulamalarının en tartışılan sonuçlarından biri afetzedelerin yaşam biçimleriyle uyumsuz yeni yerleşim alanlarının oluşturulmasıdır. Memnuniyetsizlikle sonuçlanan bu durum, ya yerleşim alanlarının terkedilmesine ya da kullanıcı eliyle değişikliğe uğratılmasına neden olmaktadır. Konut üretim süreci sadece bir barınma probleminin çözümü olarak görülmemeli, tüm toplumsal ihtiyaçlara cevap veren bir fiziksel çevre yaratma eylemi olarak ele alınmalıdır.

Bu bă̆lamda, yapılan çalışma ile toplumların yaşam kalitesini etkileyen sosyal sürdürülebilirlik parametreleri derlenerek Türkiye'de deprem sonrası üretilmiş toplu konut örnek alanları özelinde değerlendirilmiştir. Çalışma kapsamında veri toplamak için gözlem, anket ve görüşme tekniği kullanılmıştır. Anket çalışmasında kullanıcıların demografik özellikleri dikkate alınarak yaşadıkları konutu ve yapılı çevreyi değerlendirmeleri istenmiş̧ir. Türkiye'nin doğusunda bulunan Bingöl İlinde 2003 depremi sonrası yapılmış olan İnönü, Uydukent ve İçmeler Mahallesi toplu konutlarında yaşayan 207 konut kullanıcısıyla yüz yüze görüşülerek basit rastlantısal örneklem yöntemi ile anket çalışması yürütülmüş ve veriler elde edilmiştir. Çalışma kapsamında "Afet sonrası kalıcı konut üretiminde sosyal sürdürülebilirlik parametrelerinin dikkate alınması kullanıc memnuniyetinde önemli role sahiptir" hipotezi irdelenmiştir.

Sonuç olarak; konutun, sosyal, kültürel ve bölgesel özelliklerle uyumu, kullanıcı katılımı, yeniden yerleşimin benimsenmesi, aidiyet duygusu, ortak değerlerin pekişmesi, güven hissi, kimlik ve yaşam kalitesinde iyileşme gibi parametrelerin kullanıcı memnuniyetini önemli düzeyde etkilediği tespit edilmiştir.

Anahtar Kelimeler: Kahıı afet konutları, sosyal sürdürülebilirlik, kullanıcı memnuniyeti, toplu konutlar, deprem.

\footnotetext{
${ }^{1}$ Dr. Öğr. Üyesi, Bingöl Üniversitesi, E-mail fkvarolgunes@bingol.edu.tr idealkent @ Kent Araştırmaları Dergisi (Journal of Urban Studies) 


\title{
Evaluation of Social Sustainability Performance in Post-disaster Permanent Housing: Case of Bingöl
}

\author{
Fatma Kürüm Varolgüneş ${ }^{2}$ \\ ORCID: 0000-0002-3214-4274
}

\begin{abstract}
One of the most controversial results of permanent housing practices after a disaster is the creation of new residential areas that are incompatible with the way of life of disaster victims. This situation, resulting in dissatisfaction, either causes residential areas to be abandoned or modified by the user. In addition, it reveals that the housing production process should not be seen only as a solution to the housing problem, and the importance of creating new residential areas considering all social needs.

With this study, social sustainability parameters affecting the quality of life of communities were compiled and evaluated in the context of mass housing project areas produced after earthquakes in Turkey. The majority of mass housing production in Turkey is carried out by the Housing Development Administer (TOKI). Observation, questionnaire and interview techniques were used to collect data within the scope of the study. In the survey study, users were asked to evaluate their housing and built environment by taking into account their demographic characteristics. 207 residential users living in Inonu, Uydukent and Içmeler neighborhood mass housing, which were made after the 2003 earthquake in Bingöl in eastern Turkey, were interviewed face-to-face and surveyed by simple random sampling method and data on the subject were obtained. As part of the study, the hypothesis that "taking into account social sustainability parameters in the production of post-disaster permanent housing plays an important role in user satisfaction" was examined.

As a result, housing social, cultural and regional characteristics for compliance with the restructuring settlement and the adoption of a sense of belonging, shared values strengthen a sense of trust, identity, improvement in quality of life, user participation in design, the improvement of living standards the impact on parameters such as user satisfaction has been determined to be significant..
\end{abstract}

Keywords: Permanent housing, social sustainability, user satisfaction, mass housing, earthquake.

${ }^{2}$ Dr. Öğr. Üyesi, Bingöl Üniversitesi, E-mail fkvarolgunes@bingol.edu.tr

idealkent @ Kent Araştırmaları Dergisi (Journal of Urban Studies)

http://idealkentdergisi.com

Geliş Tarihi Received Date: 22.10.2020 Kabul Tarihi Accepted Date: 14.04.2021 


\section{Giriş}

Depremler gerçekleştikleri bölgelerde sadece fiziksel tahribata değil, ayn zamanda büyük bir sosyal tahribata da neden olurlar. Hızlı konut tedarik etme zorunluluğu, depremin gerçekleştiği bölgenin sosyo-kültürel koşullarının ve kullanıcı ihtiyaçlarının göz ardı edilmesine neden olmaktadır (Johnson, 2007, s. 38). Deprem sonrası konut ve yapılı çevre üretimi sırasında karşılaşılan en önemli problemlerden biri depremzedelerin yaşam biçimleriyle uyumsuz yeni yerleşim alanlarının oluşturulmasıdır. Kürüm Varolgüneş (2021) kullanıcı memnuniyetini sağlamayan yerleşim bölgelerinde konutların, ya kısa sürede "kontrolsüz ekleme, büyütme, malzeme değiştirme" gibi değişikliklere uğratıldığını ya da tamamen terk edildiğini belirtmekte ve yeniden yerleşim alanlarında kullanıcı katılımının önemini vurgulamaktadır.

İçinde yaşadığımız fiziksel çevre ve sosyal yapının kimliğini yansıtan en önemli yapı tipi konuttur (Rapoport, 1977, s. 24). Konut, bir bireyin gündelik hayatındaki sığınağı, sosyo-ekonomik yapıdaki statüsü, kendisinin simgesi ve birçok psikolojik ve sosyal aktiviteyi gerçekleştirdiği yerdir (Franscescato, Wiedemann, ve Anderson, 1987, s.48; Speare, 1974, s.76). Konut projelerinin yapımı sadece bir barınma probleminin çözümü olarak görülmemeli, tüm toplumsal ihtiyaçlara cevap veren bir fiziksel çevre yaratma eylemi olarak ele alınmalıdır (Hayles, 2010, s.115) ve yeniden yapım süreci ekonomik ve sosyal bakımdan bölgenin kalkınması ile birlikte düşünülmelidir (Carrasco, Ochiai ve Okazaki, 2017 s. 180; Ingirige, Jones ve Keraminiyage, 2013, s. 357; Jamshed, Rana ve McMillan, 2019 s. 303). Bu nedenle yaşam kalitesine etki eden parametrelerin konuta yansımasının değerlendirilmesi ve gerekli adımların atılması, konut kullanıcılarının gelecekte daha sürdürülebilir, konforlu ve işlevsel bir yaşam sürmesi açısından olumlu sonuçlar yaratabilecektir. Gerek Türkiye'de, gerekse dünyanın diğer ülkelerinde, inşaat yatırımlarında standart olarak geliştirilen; demografik yapı ve çevre ilişkileri gözetilmeden yapılan tasarım çalışmaları, yap üretiminin kullanım amaçlarına ulaşmasını engellemektedir. Bu yapılar kullanıcılarıyla uyumsuz ve ihtiyaçlara cevap vermeyen yaşam alanları sorunu olarak karşımıza çıkmaktadır. Bu problemi ortaya koymak ve çözüm önerileri geliştirmek için dünyanın farklı bölgelerinden örnek çalışmalar literatüre kazandırılmalıdır. Kowaltowski, Muianga ve Granja (2019), yaptı̆̆ı araştırmada bina ve tasarım kalitesiyle ilgili yapılan çalışmaların yetersizliğini vurgulamıştır. Literatürde çeşitlilik artıkça belirlenen parametrelerin uygulanabilirliği ve performansı test edilebilecektir. 
Bu bağlamda, yapılan çalışma ile toplumların yaşam kalitesini önemli düzeyde etkileyen sosyal sürdürülebilirlik parametreleri yerli ve yabancı literatürden taranmıştır. Bu parametreler Türkiye'de deprem sonrası üretilen toplu konut projelerinde örneklendirilmiştir. Türkiye'de toplu konut üretiminin büyük çoğunluğu Toplu Konut İdaresi Başkanlığı (TOKI) tarafından gerçekleştirilmektedir. Vaka çalışması için, Bingöl ilinde 2003 depremi sonrası üretilen toplu konut alanlarına yoğunlaşılmıştır. 2003 depreminden sonra yapılan TOKİ konutları Türkiye'nin birçok yerinde uygulanmıştır. Yapılan bu çalışma ile sosyal sürdürülebilirlik için belirlenmiş parametrelerin, standart bir proje uygulamasında ne kadar sağlanabildiği irdelenmiştir. Ayrıca yaşam kalitesini etkileyen faktörlerin bu bölgedeki öncelik durumu ortaya konmuştur. Çalışmada ilk olarak sürdürülebilirlik kavramının ne olduğu ve neden sosyal sürdürülebilirlik başlığının ön plana çıkarıldığı literatür araştırması yardımıyla anlatılmıştır.

\section{Sürdürülebilirlik ve Sosyal Sürdürülebilirlik}

Gelecek kuşakların ihtiyaçlarını karşılayabilme olanağından ödün vermeksizin günümüz kuşaklarının ihtiyaçların karşılayabilme (World Commission on Environment and Development, 1987) hedefiyle gündeme gelen "sürdürülebilirlik" kavramı, 20. yüzyıl sonlarına doğru uluslararası antlaşmalarla küresel bir uygulama planı haline gelmiştir. Sürdürülebilir kalkınma için, ekonomik büyüme, sosyal gelişme ve çevrenin etkin bir şekilde korunması göz ardı edilemez üç temel öğedir (Moldan, Janoušková ve Hák, 2012, s. 8). Todd ve Geissler (1999) yaptıkları çalışmada "sürdürülebilirlik; ekolojik, ekonomik ve sosyal boyutları içerir ve (i) kaynak yönetimi, (ii) ekonomik canlılık, ve (iii) sosyal yaşam konuları dikkate alınarak kriterler belirlenir" demiştir. Ortiz, Castells ve Sonnemann (2009) ise "sürdürülebilir kalkınma, insanların bir bütün olarak yaşamayı hedeflemelerine, şimdiki ve gelecek nesiller için sosyal, ekonomik ve çevresel koşulların sürekli iyileştirilmesini tasarlamalarına olanak tanıyan yaşam kalitesi de dâhil olmak üzere birçok anlam taşıyabilir" demektedir. Sürdürülebilir kalkınma için her ne kadar farklı tanımlar yapılsa da hepsinde ortak hedef, geleceği de sahiplenerek herkesin daha iyi bir hayata ilişkin beklentilerinin karşılanmasını sağlamaktır. Geçmiş deneyimler bu yaklaşımın önemini daha iyi vurgulamaktadır. Zimmermann, Althaus ve Haas (2005), "sürdürülebilirlik, uygun bir ekonomik çerçeve ile desteklenen istikrarlı bir sosyal düzenin, Dünya'nın genel ekolojik kapasitesini 
aşmadan uzun vadede hakim olabileceği bir devlet yönetimi" olarak tanımlanmaktadır. Buna göre, sürdürülebilir bir topluma ulaşmak için insan faaliyetinin çeşitli alanlarında gerekli katkıyı sunmak için düzenlemeler yapılmalidir.

Genel olarak çevresel, ekonomik ve sosyal boyutlar arasındaki karşlıklı ilişkiler, sürdürülebilirlik kavramının ayrılmaz parçaları olarak kabul edilse de, öncelik çevresel ve ekonomik sürdürülebilirlik konularına verilmiştir. Vallance, Perkins ve Dixon (2011), yapılan araştırmalarda sosyal sürdürülebilirlik verilerinin ihmal edilmesinin sonuçları belirsiz ve yetersiz teoriler geliştirilmesine yol açtığını iddia etmiştir. Yine bazı çalışmalarda sosyal sürdürülebilirliğin önemi vurgulanarak, literatürde çeşitli tanımlamalar yapılmıştır. Örneğin; Holden (2012), sosyal sürdürülebilirliğin “uyumlu sosyal ilişkileri sağlayan, sosyal bütünleşmeyi geliştiren ve tüm toplum için yaşam koşullarını iyileştiren bir kentsel gelişim süreci" olduğunu belirtirken, Gomaa ve Sakr (2015), sosyal sürdürülebilirliğin "sosyal bütünlüğün arttırılmasını, sosyal/kültürel niteliklerin ve yer duygusunun korunmasını, güvenli bir ortamın oluşturulmasını sağlayan bir gelişim süreci" olarak tanımlamıştır. Littig ve Griessler (2005), sosyal sürdürülebilirliği “doğa ile toplum ilişkilerinin niteliği" ve "toplumun kendi içindeki ilişkilerinin niteliği" olarak tanımlarken, Sachs (1999) ise, sosyal sürdürülebilirlikten söz edilebilmesi için "eşitlik, demokrasi ve sosyal adalet" gibi bir dizi unsurdan söz edilmesi gerektiğini belirtir. Mevcut literatürde sosyal sürdürülebilirliğe ait çok sayıda tanım, terim, yaklaşım ve araç bulunmasına rağmen yakın zamana kadar hala belli bir ölçüt tanımı yapılamamıştır (Missimer, Robèrt ve Broman, 2017, s. 48). Bu nedenle ortak bir ölçüt sistemi oluşturmak biraz zordur (Colantonio ve Dixon, 2011, s. 34-35; Hutchins ve Sutherland, 2008, s. 1691; Weingaertner ve Moberg, 2014, s. 126). Bu çalışmada farklı disiplinlerde kullanılan ölçütler derlenerek özetlenmiştir (Tablo 1). Belirlenen ölçütler deprem sonrası oluşturulan konut yerleşim alanları örneğinde, yerel ölçekte değerlendirilmiştir. Literatürde yerel ölçekte yapılan çalışmaların kentsel ölçeklere de entegre edilebileceği dile getirilmiştir. Shirazi ve Keivani (2019), mahalle (semt) ölçeğinde yapmış oldukları bir çalışmada, sosyal sürdürülebilirlik parametrelerinin toplum ölçeğinden, kentsel politikalara ve kent planlama şemalarının oluşturulmasına kadar, yani mikro ölçekten makro ölçeğe her bölgeye entegre edilebileceğini belirtmişlerdir. Yine, Shirazi ve Keivani (2019)'a göre mahalle ölçeği, yerel yönetimlerin sosyal sorunları ve zorlukları ele almaları için pratik bir ölçektir. Kentsel dönüşüm ve yeniden geliştirme projeleri, gecekondu iyileştirme programları gibi doğrudan toplumsal sonuçları ve hedefleri olan çok 
sayıda mahalle odaklı girişim ve program vardır. Sosyal sürdürülebilirlik, bu programların sosyal başarılarını değerlendirmek ve ölçmek için teorik ve ampirik bir çerçeve sağlayabilir. Sosyal sürdürülebilirlik söylemi, mimarlar, şehir planlamacılar ve karar vericiler için yeni gelişmelerin sosyal yönlerini ele almak ve bunları zaman içinde izlemek için güvenli bir başlangıç noktası sağlayabilir.

Tablo 1. Literatürden derlenen sosyal sürdürülebilirlik ölçütleri

\begin{tabular}{|c|c|c|}
\hline Ölçüt & Alt-ölçüt & Açıklama \\
\hline $\begin{array}{l}\text { Eşitlik/Adalet (Hutc- } \\
\text { hins ve Sutherland, } \\
2008, \text { s. } 1692 \text { ) }\end{array}$ & $\begin{array}{l}\text { Gelir eşitliği } \\
\text { Cinsiyet eşitliği } \\
\text { Nesiller arası eşitlik }\end{array}$ & $\begin{array}{l}\text { Sosyal yönden sürdürülebilir } \\
\text { bir toplum doğru, adil, kapsa- } \\
\text { yıcı ve demokratiktir. Sosyal } \\
\text { yönden sürdürülebilir toplum } \\
\text { şu anki ve gelecek nesiller için } \\
\text { iyi kalitede bir yaşam sağlar. }\end{array}$ \\
\hline $\begin{array}{l}\text { Sosyal ve kültürel ya- } \\
\text { şam (Gomaa ve Sakr, } \\
2015 \text {, s. 205-206). }\end{array}$ & $\begin{array}{l}\text { Kimlik } \\
\text { Aidiyet } \\
\text { Yer ve kültür duygusu (Williams } \\
\text { ve Dair, 2007, s. 140). } \\
\text { Ortak değerler } \\
\text { Komşuluk ilişkileri ve etkileşimi } \\
\text { Juan vd., 2019, s. 269). }\end{array}$ & $\begin{array}{l}\text { Yaşam biçimleri } \\
\text { Ortak-özel kullanım alanları } \\
\text { Toplumun iyileştirilmesi ve } \\
\text { ihtiyaçlarını karşılayan sosyal } \\
\text { gelişme (Akadiri, Chinyio ve } \\
\text { Olomolaiye, 2012, s. 141). } \\
\text { Kültürel mirası korumak }\end{array}$ \\
\hline $\begin{array}{l}\text { Sosyal altyap1 } \\
\text { (Woodcraft, 2015, s. } \\
138 \text { ) }\end{array}$ & $\begin{array}{l}\text { Yerel ve bölgesel ekonomiye katkı } \\
\text { Eğitim ve öğretim alanları } \\
\text { Woodcraft, 2015, s. 140; Woodcraft } \\
\text { ve Dixon, 2013, s. 475). } \\
\text { Kamu tesisleri } \\
\text { Sosyal alanlar } \\
\text { Açık alanlar } \\
\text { Çocuk etkinlik alanları } \\
\text { Depolama, park ve atık hizmetleri }\end{array}$ & $\begin{array}{l}\text { Toplumun yaşam kalitesini } \\
\text { geliştiren tesisler ve destek bi- } \\
\text { rimleri; okullar, sağlık alanları, } \\
\text { sosyal alanlar, ulaştırma ağları } \\
\text { geliştirmek. Yerel halk ile iş- } \\
\text { birliği yapmak. }\end{array}$ \\
\hline $\begin{array}{l}\text { Konut ve yapılı çevre } \\
\text { tasarımı (Juan vd., 2019, } \\
\text { s. 278). }\end{array}$ & $\begin{array}{l}\text { Erişilebilirlik } \\
\text { Yeşil binalar } \\
\text { Çevresel yenilikler } \\
\text { Esnek planlama } \\
\text { Kullanıcı memnuniyetini sağlayan } \\
\text { konut } \\
\text { Alt yapı ve hizmetler } \\
\text { Çevre ve mahalle ilişkisi } \\
\text { Bina kalitesi } \\
\text { Bina imajı }\end{array}$ & $\begin{array}{l}\text { İnsan odaklı tasarım (Littig ve } \\
\text { Griessle, 2005, s.69). İnsanlar } \\
\text { konutlarında ve yapılı çev- } \\
\text { rede kendilerini rahat, sağlıklı } \\
\text { ve güvende hissedebilmelidir. } \\
\text { Bu durum "optimum koşulla- } \\
\text { rın sağlanması" olarak tanım- } \\
\text { lanıyor. }\end{array}$ \\
\hline $\begin{array}{l}\text { Güvenlik (Shirazi ve } \\
\text { Keivani, 2019, s. 452; } \\
\text { Woodcraft, 2015, s.139) }\end{array}$ & $\begin{array}{l}\text { Korunma } \\
\text { Toplum güvenliği } \\
\text { Özel hayatın korunması (Mahre- } \\
\text { miyet) (Juan vd., 2019, s. 278). }\end{array}$ & $\begin{array}{l}\text { Konutlar ve yapılı çevrede; } \\
\text { mahremiyet, sosyal iletişim, } \\
\text { özgürlük, seçim ve özerklik } \\
\text { gibi özellikler kazandırılmalı- } \\
\text { dır. }\end{array}$ \\
\hline
\end{tabular}


Sağlık, yaşam kalitesi ve iyileşme Woodcraft, 2015, s.139)
Yaşam koşullarının iyileştirilmesi

(Williams ve Dair, 2007, s.139).

Toplum sağlığı(Singhaputtangkul vd, 2013, s. 317)

Medikal ihtiyaçlar(Juan vd., 2019,

s. 278).
Sağlıklı konutlar ve yapılı çevre üretimi için konfor koşullarının oluşturulmasına dikkat edilmelidir.

\section{Yöntem}

Çalışma kapsamında veri toplamak için gözlem, anket ve görüşme tekniği kullanılmıştır. Anket çalışmasında kullanıcıların sosyo-demografik bilgilerle birlikte yaşadıkları konutu ve yapılı çevreyi değerlendirmeleri istenmiştir. Anket soruları literatür araştırması ile elde edilen ölçütlerin derlenmesiyle oluşturulmuştur (Tablo 1). Türkiye'nin doğusunda bulunan Bingöl Illinde 2003 depremi sonrası yapılmış olan İnönü, Uydukent ve İçmeler Mahallesi toplu konutlarında yaşayan 207 konut kullanıcısıyla yüz yüze görüşülerek basit rastlantısal örneklem yöntemi ile anket uygulanmış ve konu ile ilgili veriler elde edilmiştir. Yüz yüze anket uygulaması ile cevaplama oranını artırma ve gözlem yolu ile başka bilgilerin de elde edilmesi imkânı sağlanmıştır. Örneklem büyüklüğü hesaplanırken üç çalışma alanındaki konut sayısı dikkate alınmıştır. Buna göre İnönü Mahallesi TOKİ konutlarında 80, Uydukent mahallesi TOKİ konutlarında 68, İçmeler mahallesi TOKİ konutlarında ise 59 olmak üzere toplam anket yapılacak konut sayısı belirlenmiştir.

Çalışma kapsamında incelenen hipotez şu şekildedir:

Hipotez 1: Afet sonrası kalıcı konut üretiminde sosyal sürdürülebilirlik parametrelerinin dikkate alınması kullanıc memnuniyetinde önemli role sahiptir.

Bu hipotez doğrultusunda farklı sosyo-demografik yapıya sahip afetzedelerin kalıcı afet konutlarıyla ilgili beklenti ve memnuniyet seviyeleri, belirlenen sosyal sürdürülebilirlik parametreleri ile ilişkilendirilerek sorgulama yapilmıştır.

Alan çalışmasına başlanmadan önce araştırma evreni belirlenmiş ve örneklemin netleşmesi ile niteliksel ve niceliksel bir yöntemle verilere ulaşılmıştır. Cronbach Alpha iç tutarlılık katsayısı yapılan hesaplarla 0.79 olarak tespit edilmiştir. Bu veri ışığında araştırmanın güvenilir özelliğe sahip olduğu söylenebilir. Bulgular bölümünde veriler analiz edilmiş ve yorumlanmıştır.

Çalışma alanı olarak tercih edilen Bingöl ili Türkiye'nin doğusunda yer alır (Kürüm Varolgüneş, 2019, s. 210). Doğu Anadolu Fay Sistemi ve Kuzey Anadolu Fay Sistemi'nin kesişim bölgesinde bulunan Bingöl ili depremsellik 
açısından oldukça etkindir (Şekil 1). Tarih boyunca büyük depremler meydana gelmiş olan ilde son yüzyılda Richter ölçeğine göre 1971 yılındaki 6,8 ve 2003 yılında 6,4 büyüklüğündeki depremler ciddi hasar meydana getirmiştir (Afet ve Acil Durum Yönetim Başkanlığ1 [AFAD], 2019). Depremlerden sonra kent neredeyse tamamen yeniden yapılanmaya gitmiştir. Özellikle $2003 \mathrm{dep}-$ remi sonrası yeniden yapılanmanın en önemli aktörü TOKİ olmuştur ve Bingöl'de birçok toplu konut projesi üretmiştir. Bu çalışmada 2003 depreminden sonra yapılan toplu konut alanlarından 3 (üç) farklı mahallede çalışma yapılmıştır. İnönü Mahallesi’nde “Kentsel Dönüşüm” kapsamında yapılan konutlar (Şekil 2), 1971 deprem konutlarının yıkılmasıyla gerçekleştirilmiştir. Toplam 1346 konut inşa edilmiştir. 36 blok $120 \mathrm{~m}^{2}$ büyüklüğünde $3+1$, 7 blok 192 $\mathrm{m}^{2}$ büyüklügünde $4+1$ olmak üzere toplam 43 blok yapılmıştır. Uydukent Mahallesinde bulunan TOKİ deprem konutları 1536 adet 3+1 olarak yapılmıştır. Yine Bingöl-Genç Yolu İçmeler mevkiinde bulunan TOKİ konutları alt gelir gurubu için 482 adet 75 metre kare büyüklüğünde $2+1$ niteliğinde inşa edilmiştir. Sosyal konut projesi kapsamında inşa edilen 117 konut ise 107 metrekare büyüklüğünde 3+1 olarak yapılmıştır (Şekil 3).

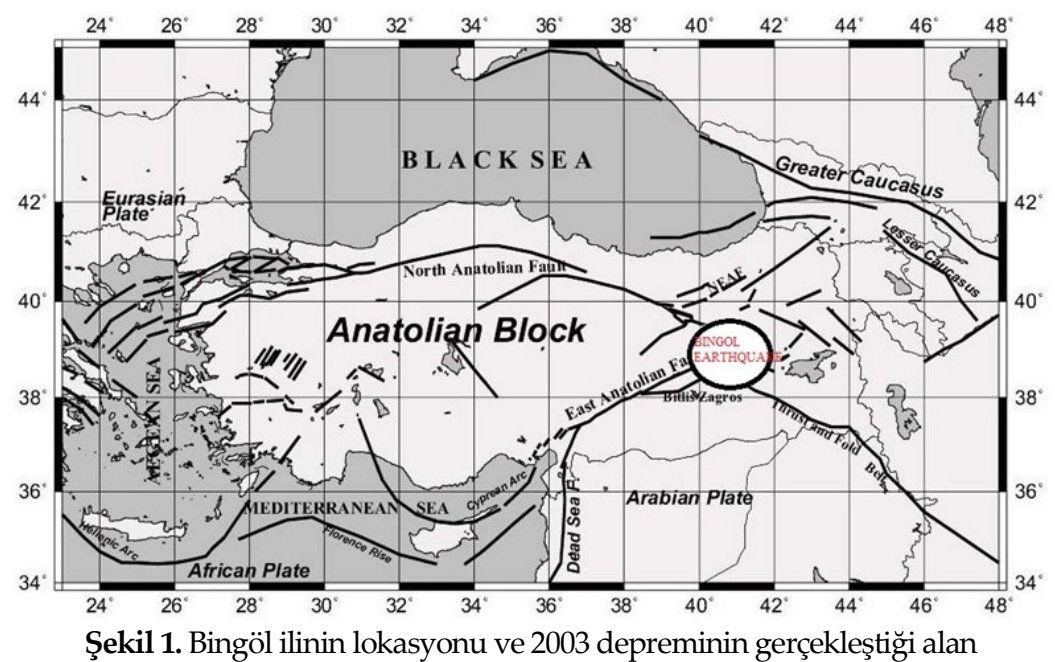

(Kalafat, Güneş ve Arpat, 2003). 


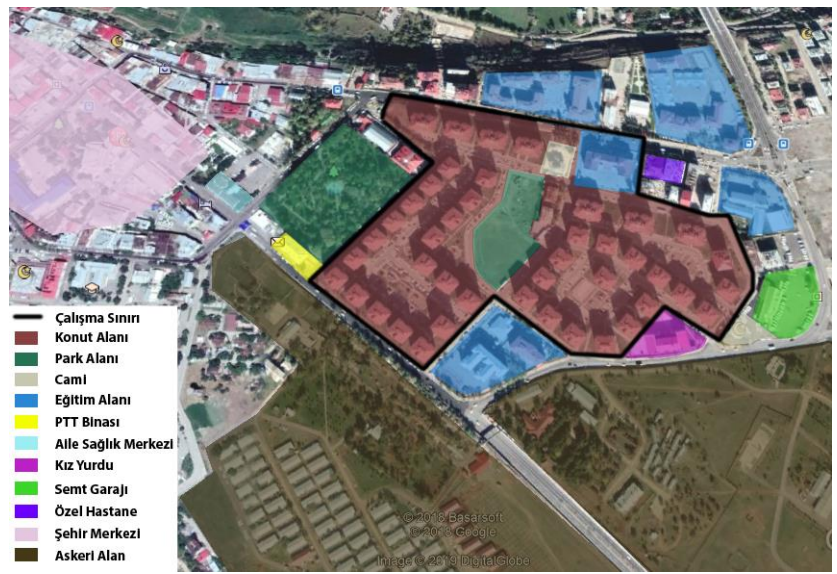

Şekil 2. İnönü Mahallesi Toki konutları yerleşimi
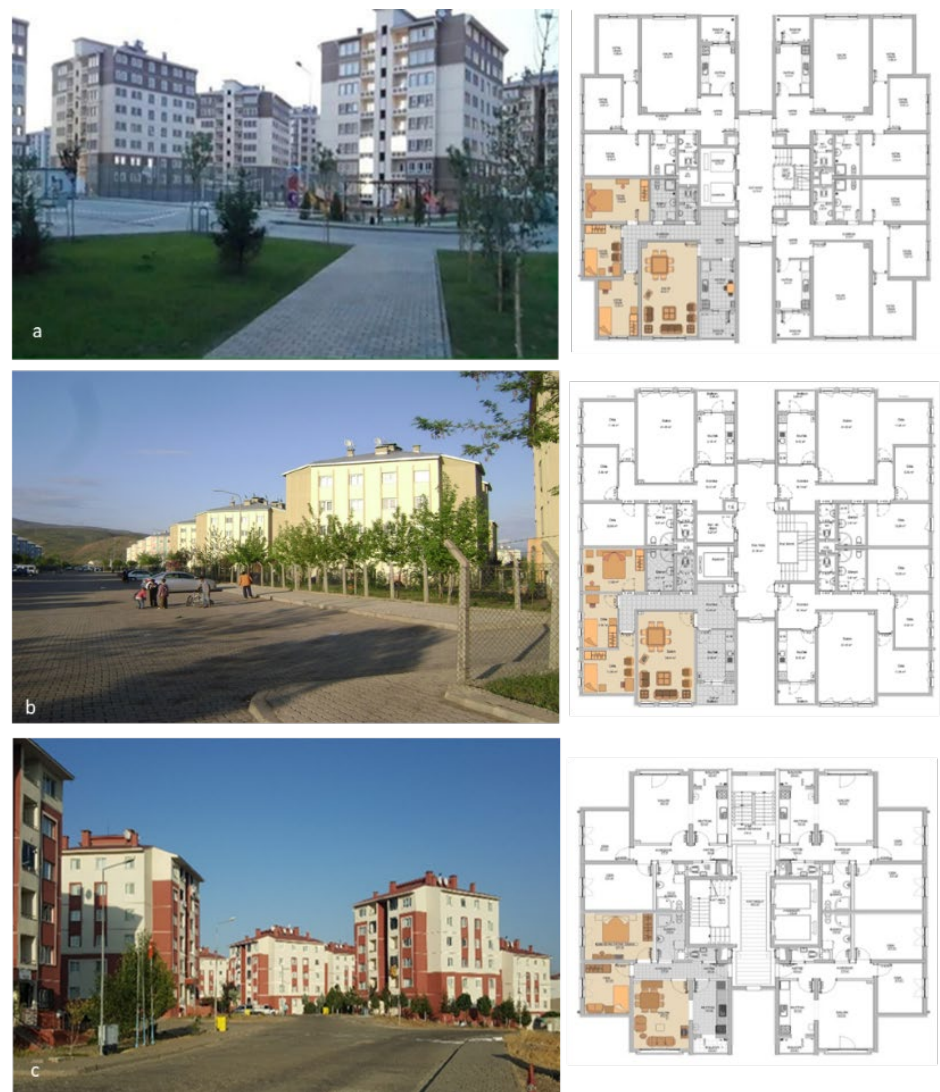

Şekil 3. Çalışma alanından genel görünüm ve planlar (a-İnönü Mahallesi TOKİ konutları, b-Uydukent Mahallesi TOKİ konutları, c-İçmeler Mahallesi TOKİ Konutları). 


\section{Bulgular}

Toplu konut bölgelerinde kalıcı konut kullanıcılarıyla anket çalışması gerçekleştirilmiş ve anket soruları, literatürden derlenen sosyal sürdürülebilirlik parametreleri dikkate alınarak hazırlanmıştır. Bu sorularla yeni yapılı çevrenin, kullanıcıların fiziksel, ekonomik ve sosyal yaşantıları üzerindeki etkisinin tespiti hedeflenmiştir. Çalışmada öncelikle, yerleşmelerin sosyal ve demografik yapısını tespit etmek için cinsiyet, yaş, eğitim, mülk durumu, hane halkı büyüklüğü ve gelir durumu, yer değiştirme ve kentte yaşam süresi durumlarına yönelik tespitler yapılmıştır.

\section{Demografik Bulguların Değerlendirilmesi}

Tablo 2'de, alan çalışmasının yapıldığı kalıcı afet konutları kullanıcılarının demografik yapısı ortaya konulmuştur. Bu konutların kullanıcı profilinin belirlenmesi, uygulanan toplu konut projeleri ile kullanıc uyumunun ortaya konması açısından önemlidir. Yapılan çalışmada elde edilen veriler; cinsiyet, yaş, gelir durumu, eğitim durumu, kullanıcı sayısı, mülk durumu, yer değiştirme durumu ve kentte yaşam süresi başlıkları ile frekans (n) ve yüzde (\%) değerleri dikkate alınarak belirlenmiştir. Katılımcıların \% 49'u kadın, \% 51'i erkektir. 20 yaş üstü konut kullanıcıları ile anket çalışması gerçekleştirilmiştir. İnönü Mahallesi konutlarında eğitim ve gelir durumunun diğer mahallelere göre daha iyi olduğu tespit edilmiştir. Katılımcıların çoğunluğu 5 ve üzeri kullanıcı sayısına sahiptir. Toplam katılımclar arasında ev sahibi ve kiracı olma durumu eşittir. Ancak üç mahalle karşılaştırıldığında bu oranlar arasında önemli farklar tespit edilmiştir. Uydukent mahallesi ve İçmeler mahallelerinde bulunan toplu konutlarda kırsaldan göç yoluyla yerleşenlerin oranı fazladır ancak İnönü Mahallesi toplu konutlarında ise kent merkezinde uzun süreli yaşayan kullanıcıların çoğunlukta olduğu tespit edilmiştir.

Tablo 2. Katılımcıların (TOKİ kullanıcısı) demografik özellikleri

\begin{tabular}{|c|c|c|c|c|c|}
\hline & & $\begin{array}{l}\text { İnönü } \\
\text { Mahallesi } \\
\text { ( A) }\end{array}$ & $\begin{array}{l}\text { Uydukent } \\
\text { Mahallesi } \\
\text { (B) }\end{array}$ & $\begin{array}{l}\text { İçmeler Mahallesi } \\
\text { (C) }\end{array}$ & Toplam \\
\hline & & $\begin{array}{l}\mathrm{N}=80 \\
\mathrm{~F}(\%)\end{array}$ & $\begin{array}{l}\mathrm{N}=68 \\
\mathrm{~F}(\%)\end{array}$ & $\begin{array}{l}\mathrm{N}=59 \\
\mathrm{~F}(\%)\end{array}$ & $\begin{array}{l}N=207 \\
F(\%)\end{array}$ \\
\hline Cinsiyet & $\begin{array}{l}\text { Kadın } \\
\text { Erkek }\end{array}$ & $\begin{array}{l}52(65) \\
28(35)\end{array}$ & $\begin{array}{l}26(38) \\
42(62)\end{array}$ & $\begin{array}{l}23(39) \\
36(61)\end{array}$ & $\begin{array}{l}101(49) \\
106(51)\end{array}$ \\
\hline
\end{tabular}




\begin{tabular}{|c|c|c|c|c|c|}
\hline \multicolumn{6}{|l|}{ Yaş } \\
\hline & $20-30$ & $38(48)$ & $24(35)$ & $18(31)$ & $80(39)$ \\
\hline & $31-40$ & $31(38)$ & $18(26)$ & $26(44)$ & $75(36)$ \\
\hline & $>40$ & $11(14)$ & $26(39)$ & $15(25)$ & $52(25)$ \\
\hline \multicolumn{6}{|c|}{ Gelir durumu } \\
\hline & $1500-3000$ & $27(34)$ & $22(32)$ & $39(66)$ & $88(43)$ \\
\hline & $3001-6000$ & $40(50)$ & $38(56)$ & $18(31)$ & $96(46)$ \\
\hline & $6001 \leq \ldots$ & $13(16)$ & $8(12)$ & $2(3)$ & $23(11)$ \\
\hline \multicolumn{6}{|c|}{ Eğitim } \\
\hline & İlköğretim & $8(10)$ & $8(12)$ & $10(17)$ & $26(13)$ \\
\hline & Ortaöğretim & $32(40)$ & $37(54)$ & $31(53)$ & $100(48)$ \\
\hline & Lisans & $37(46)$ & $21(31)$ & $18(30)$ & $76(37)$ \\
\hline & Lisansüstü & $3(4)$ & $2(3)$ & $0(0)$ & $5(2)$ \\
\hline \multicolumn{6}{|c|}{ Kullanıcı sayısı } \\
\hline & 2 & $10(13.5)$ & $4(5)$ & $2(3)$ & $16(8)$ \\
\hline & 3 & $12(15)$ & $10(15)$ & $0(0)$ & $22(10)$ \\
\hline & 4 & $20(25)$ & $10(15)$ & $15(26)$ & $45(22)$ \\
\hline & 5 ve üzeri & $38(47.5)$ & $44(65)$ & $42(71)$ & $124(60)$ \\
\hline \multicolumn{6}{|c|}{ Mülk durumu } \\
\hline & Ev sahibi & $36(45)$ & $28(41)$ & $40(68)$ & $104(50)$ \\
\hline & Kiracı & $44(55)$ & $40(59)$ & $19(32)$ & $103(50)$ \\
\hline \multicolumn{6}{|c|}{ Yer değiştirme durumu } \\
\hline & Yer değiştirdi & $25(31)$ & $50(74)$ & $48(81)$ & $123(59)$ \\
\hline & Yer değiştirmedi & $55(69)$ & $18(26)$ & $11(19)$ & $84(41)$ \\
\hline \multicolumn{6}{|c|}{ Kentte yaşam süresi } \\
\hline & 5 yildan az & $18(22.5)$ & $16(23)$ & $10(17)$ & $44(21)$ \\
\hline & $5-10$ y1l & $18(22.5)$ & $40(59)$ & $40(68)$ & $98(48)$ \\
\hline & 10 yıldan fazla & $44(55)$ & $12(18)$ & $9(15)$ & $65(31)$ \\
\hline
\end{tabular}

\section{Alanda Yapılan Gözlemlerin Yorumlanması}

Anket çalışmaları sırasında seçilmiş TOKİ konutlarının (kalıcı afet konutları) bulunduğu üç alanda da görsel analizler yapılmıştır. Bu analizler alanda çekilen fotoğraflar, yapılan görüşmeler ve kurumlardan elde edilen projeler kullanılarak ortaya konmuştur. Bu analizler sosyal sürdürülebilirlik parametreleri 1şığında yorumlanarak Tablo 3'de özet olarak sunulmuştur.

Tablo 3. Gözlemler 1şı̆̆ında yapılan analiz sonuçları

\begin{tabular}{llll}
\hline 1-Eşitlik/Adalet & $\begin{array}{l}\text { İnönü } \\
\text { Mahallesi (A) }\end{array}$ & $\begin{array}{l}\text { Uydukent } \\
\text { Mahallesi (B) }\end{array}$ & $\begin{array}{l}\text { İçmeler } \\
\text { Mahallesi (C) }\end{array}$ \\
\hline Gelir eşitliği & $\begin{array}{l}\text { Alt ve orta gelir } \\
\text { grubu }\end{array}$ & $\begin{array}{l}\text { Alt ve orta gelir } \\
\text { grubu }\end{array}$ & Alt gelir grubu \\
& $\begin{array}{l}\text { Üst Gelir Grubu } \\
\text { Cinsiyet eşitliği }\end{array}$ & $\begin{array}{l}\text { Üç konut bölgesinde de cinsiyete yönelik her hangi bir } \\
\text { çalışma yapılmamıştır. }\end{array}$ \\
\hline Nesiller arası eşitlik & $\begin{array}{l}\text { U̧ konut bölgesinde de yaşlılara yönelik sosyal alanlar } \\
\text { düşünülmemiştir. }\end{array}$ \\
\hline
\end{tabular}




\begin{tabular}{|c|c|c|c|}
\hline 2-Sosyal ve kültürel yaşam & A & B & $\mathrm{C}$ \\
\hline Kimlik & \multicolumn{3}{|c|}{$\begin{array}{l}\text { Mahallenin kimliğini TOKİ yapıları oluşturmaktadır. } \\
\text { Yerel mimariden izler taşımamaktadır. } \\
\text { Eski yerleşim alanlarıyla ilişki kurulmamıştır. } \\
\text { Geometrik kurguda tasarımlar yapılmıştır. } \\
\text { Yollara cephe veren yapılar genellikle ayrık nizamda, } \\
\text { yüksek katlı ve birbirine benzer mimari stillerle oluştu- } \\
\text { rulmuştur. }\end{array}$} \\
\hline Aidiyet & \multirow{3}{*}{\multicolumn{3}{|c|}{$\begin{array}{l}\text { Güvenli, huzurlu bir çevre oluşturulmuş ancak eski yer- } \\
\text { leşim alanlarıyla bağ kurulmamıştır. } \\
\text { Farklı demografik yapıya ve kültürel değerlere sahip in- } \\
\text { sanlar bir arada yaşamaktadır. } \\
\text { Yaşama alanları özel, sosyal donatılar ortak kullanım } \\
\text { alanlarında düzenlenmiştir. Bütün yapılar birbirinin ay- } \\
\text { nısıdır. }\end{array}$}} \\
\hline Yer ve kültür duygusu & & & \\
\hline Ortak değerler & & & \\
\hline Komşuluk ilişkileri ve etkileşimi & $\begin{array}{l}\text { Eğitimli kültürlü } \\
\text { insanlarla kom- } \\
\text { şuluk. } \\
\text { Konut mesafesi } \\
\text { mahremiyeti } \\
\text { sağlıyor. } \\
\text { Ortak oturma } \\
\text { alanları mevcut }\end{array}$ & $\begin{array}{l}\text { Konut mesafe- } \\
\text { leri mahremiyeti } \\
\text { sağliyor. } \\
\text { Bina ortak bah- } \\
\text { çesi var. }\end{array}$ & $\begin{array}{l}\text { Konut mesafe- } \\
\text { leri mahremiyeti } \\
\text { sağllyor. }\end{array}$ \\
\hline 3-Sosyal altyapı & A & B & $\mathrm{C}$ \\
\hline Ĕgitim ve öğretim alanları & \multicolumn{3}{|c|}{ Anaokulu, İlkokul, ortaokul, lise } \\
\hline Kamu tesisleri & \multirow{5}{*}{$\begin{array}{l}\text { Yeşil alanlar, ço- } \\
\text { cuk parkı, oto- } \\
\text { park, spor alanı, } \\
\text { atık depolama } \\
\text { alanı, }\end{array}$} & \multirow{5}{*}{$\begin{array}{l}\text { Yeşil alan, oto- } \\
\text { park }\end{array}$} & \multirow{5}{*}{$\begin{array}{l}\text { Yeşil alanlar, ço- } \\
\text { cuk park1, oto- } \\
\text { park }\end{array}$} \\
\hline Sosyal alanlar & & & \\
\hline Açık alanlar & & & \\
\hline Çocuk etkinlik alanları & & & \\
\hline $\begin{array}{l}\text { Depolama, park ve atık hizmet- } \\
\text { leri }\end{array}$ & & & \\
\hline 4-Konut ve yapılı çevre tasarımı & A & B & $\mathrm{C}$ \\
\hline Erişilebilirlik & $\begin{array}{l}\text { Okul, sağllk hiz- } \\
\text { meti ve merkeze } \\
\text { yakın } \\
\text { Engelli erişim } \\
\text { çözümleri mev- } \\
\text { cut }\end{array}$ & $\begin{array}{l}\text { Okul ve sağlık } \\
\text { hizmetine yakın } \\
\text { Engelli erişimi } \\
\text { yok }\end{array}$ & $\begin{array}{l}\text { Okula yakın } \\
\text { Engelli erişimi } \\
\text { yetersiz }\end{array}$ \\
\hline Yeşil binalar & $\begin{array}{l}\text { Yeşil bina kriter- } \\
\text { leri yok } \\
\text { Doğa ile ilişki } \\
\text { yok }\end{array}$ & $\begin{array}{l}\text { Yeşil bina kriter- } \\
\text { leri yok } \\
\text { Doğa ile ilişki } \\
\text { yok }\end{array}$ & $\begin{array}{l}\text { Yeşil bina kriter- } \\
\text { leri yok } \\
\text { Doğa ile ilişkisi } \\
\text { zayıf }\end{array}$ \\
\hline Çevresel yenilikler & Yok & Yok & Yok \\
\hline Esnek planlama & Yok & Yok & Yok \\
\hline Alt yapı ve hizmetler & Sağlanmış & Yetersiz & Yetersiz \\
\hline Çevre ve mahalle ilişkisi & Uyumsuz & Uyumsuz & Uyumsuz \\
\hline Bina kalitesi & $\begin{array}{ll}\text { Bina } & \text { kalitesi } \\
\text { kötü } & \end{array}$ & $\begin{array}{ll}\text { Bina } & \text { kalitesi } \\
\text { kötü } & \end{array}$ & $\begin{array}{l}\text { Bina kalitesi } \\
\text { kötü }\end{array}$ \\
\hline
\end{tabular}




\begin{tabular}{|c|c|c|c|}
\hline Bina imaj1 & $\begin{array}{l}\text { Yerel dokuyla } \\
\text { ve mahalleyle } \\
\text { uyumsuz }\end{array}$ & $\begin{array}{l}\text { Yerel dokuyla } \\
\text { ve mahalleyle } \\
\text { uyumsuz }\end{array}$ & $\begin{array}{l}\text { Yerel dokuyla } \\
\text { ve mahalleyle } \\
\text { uyumsuz }\end{array}$ \\
\hline 5-Güvenlik & A & B & $\mathrm{C}$ \\
\hline Korunma & \multirow{3}{*}{$\begin{array}{l}\text { Güvenlik sis- } \\
\text { temi ve koru- } \\
\text { naklı duvarlar } \\
\text { mevcut } \\
\text { Binalar arası } \\
\text { mesafe mahre- } \\
\text { miyeti sağlıyor }\end{array}$} & \multirow[t]{3}{*}{$\begin{array}{l}\text { Binalar arası } \\
\text { mesafe mahre- } \\
\text { miyeti sağlıyor }\end{array}$} & \multirow{3}{*}{$\begin{array}{l}\text { Güvenlik kulü- } \\
\text { besi mevcut. } \\
\text { Bina mesafeleri } \\
\text { yakın }\end{array}$} \\
\hline Toplum güvenliği & & & \\
\hline Özel hayatın korunması & & & \\
\hline $\begin{array}{l}\text { 6-Sağlık, yaşam kalitesi ve iyi- } \\
\text { leşme }\end{array}$ & A & B & $\mathrm{C}$ \\
\hline $\begin{array}{l}\text { Yaşam koşullarının iyileştiril- } \\
\text { mesi }\end{array}$ & \multirow{3}{*}{$\begin{array}{l}\text { Yakın mesafede } \\
\text { sağlık ocağı, } \\
\text { özel hastane ve } \\
\text { eczaneler bulun- } \\
\text { makta. } \\
\text { Açık dinlenme } \\
\text { alanı, spor alan- } \\
\text { ları, Oyun park } \\
\text { alanı mevcut }\end{array}$} & \multirow{3}{*}{$\begin{array}{l}\text { Yakın mesafede } \\
\text { sağlık ocağı ve } \\
\text { eczaneler bulun- } \\
\text { makta, oyun } \\
\text { park alanı mev- } \\
\text { cut }\end{array}$} & \multirow{3}{*}{$\begin{array}{l}\text { Yakın mesafede } \\
\text { sağlık ocağı bu- } \\
\text { lunmakta } \\
\text { Oyun park alanı } \\
\text { mevcut. }\end{array}$} \\
\hline Toplum sağlığı & & & \\
\hline Medikal ihtiyaçlar & & & \\
\hline
\end{tabular}

\section{Eşitlik/Adalet}

Alan içerisindeki açık ve yeşil alanlar yaş grupları gözetilerek düzenlenmemiştir. Konut çevresinde standart mekânlar (çocuk parkı, spor sahası, yürüyüş alanları vb.) dışında ek mekânlar bulunmamaktadır. Yaşlı erişimi İnönü ve İçmeler mahallesindeki TOKİ konutlarında dikkate alınırken, Uydukent toplu konutlarında dikkate alınmamıştır. Üç konut alanında da yaşlılar için ortak açık oturma alanları dışında farklı etkinlik alanları düzenlenmemiştir. Yapılan gözlemler sonucunda nesiller arası eşitlik sağlanamamış, projelerde birçok konuda yaşlı grubun ihtiyaçlarının dikkatte alınmadığı görülmektedir (Tablo 4). Yapılı çevre oluşturulurken cinsiyet ve gelir düzeyi ayrımı dikkate alınarak tasarımlar gerçekleştirilmemiştir. Konut ortak mekânlarında benzer donatılar görülmektedir.

Tablo 4.Yaş grubuna göre gereksinimlerin sağlanması

\begin{tabular}{|c|c|c|c|c|c|}
\hline \multirow[t]{2}{*}{ Gereksinimler } & \multirow{2}{*}{$\frac{\Xi}{\stackrel{d}{D}}$} & \multicolumn{4}{|c|}{ Yaş grubu } \\
\hline & & Çocuk & Genç & Orta Yasslı & Emekli \\
\hline \multirow[t]{3}{*}{ Donatı olanaklarının çeşitli olması } & A & $\sqrt{ }$ & - & $X$ & $\mathrm{X}$ \\
\hline & B & $X$ & $x$ & $X$ & $X$ \\
\hline & C & - & - & $X$ & $X$ \\
\hline
\end{tabular}




\begin{tabular}{|c|c|c|c|c|c|}
\hline \multirow[t]{3}{*}{ Kapalı ortak mekan alanları } & $\mathrm{A}$ & $X$ & $X$ & $X$ & $x$ \\
\hline & $\bar{B}$ & $x$ & $x$ & $x$ & $x$ \\
\hline & $\overline{\mathrm{C}}$ & $x$ & $x$ & $X$ & $x$ \\
\hline \multirow{3}{*}{$\begin{array}{l}\text { Etkin olarak kullanılabilen açık } \\
\text { yeşil alan }\end{array}$} & A & $\sqrt{ }$ & $\sqrt{ }$ & - & - \\
\hline & $B$ & $\sqrt{ }$ & - & - & $x$ \\
\hline & $\overline{\mathrm{C}}$ & $\sqrt{ }$ & $\sqrt{ }$ & - & - \\
\hline \multirow[t]{3}{*}{ Özel bahçe } & A & $X$ & $X$ & $X$ & $X$ \\
\hline & $\underline{B}$ & $X$ & $X$ & $X$ & $X$ \\
\hline & $\overline{\mathrm{C}}$ & $X$ & $X$ & $X$ & $x$ \\
\hline \multirow[t]{3}{*}{ Aktif şehirsel çevre } & $\mathrm{A}$ & $\sqrt{ }$ & $\sqrt{ }$ & $\sqrt{ }$ & $\sqrt{ }$ \\
\hline & $\mathrm{B}$ & $\sqrt{ }$ & $\sqrt{ }$ & $\sqrt{ }$ & $\sqrt{ }$ \\
\hline & $\overline{\mathrm{C}}$ & $x$ & $x$ & $x$ & $x$ \\
\hline \multirow[t]{3}{*}{ Sakin doğal çevre } & $\mathrm{A}$ & $X$ & $X$ & $X$ & $x$ \\
\hline & $\mathrm{B}$ & $X$ & $X$ & $X$ & $x$ \\
\hline & $\overline{\mathrm{C}}$ & $\sqrt{ }$ & $\sqrt{ }$ & $\sqrt{ }$ & $\sqrt{ }$ \\
\hline \multirow[t]{3}{*}{ Spor alanı } & $\mathrm{A}$ & $\sqrt{ }$ & $\sqrt{ }$ & - & - \\
\hline & $\mathrm{B}$ & $\sqrt{ }$ & $\sqrt{ }$ & - & - \\
\hline & $\mathrm{C}$ & $\sqrt{ }$ & $\sqrt{ }$ & - & - \\
\hline \multirow[t]{3}{*}{ Güneşlenme alanı } & $\mathrm{A}$ & - & - & - & - \\
\hline & $\mathrm{B}$ & - & - & - & - \\
\hline & $\mathrm{C}$ & - & - & - & - \\
\hline \multirow[t]{3}{*}{ Erişilebilirlik } & $\mathrm{A}$ & $\sqrt{ }$ & $\sqrt{ }$ & $\sqrt{ }$ & $\sqrt{ }$ \\
\hline & B & - & - & - & $X$ \\
\hline & $\mathrm{C}$ & $\sqrt{ }$ & $\sqrt{ }$ & $\sqrt{ }$ & $\sqrt{ }$ \\
\hline
\end{tabular}

\section{Sosyal ve Kültürel Yaşam}

İncelenen üç bölgede edinilen bilgilere göre afetzedelerin yeni yapılı çevrelerinde komşuluk ilişkilerini geliştirmek için site içerisinde oluşturulan açık yeşil alanları ve park alanlarını aktif olarak kullandıkları tespit edilmiştir. Özellikle İnönü Mahallesi TOKİ konutları yeşil alan ve sosyal donatı açısından diğer toplu konut bölgelerine göre daha şanslıdır. Üç çalışma alanında da mahalle kimliğini TOKİ konutları oluşturmaktadır ve kullanıcılar büyük oranda bu konuda memnuniyetsizlik dile getirmişlerdir. Kalıc konut yerleşim alanları oluşturulurken eski yerleşimlerin fiziksel, ekonomik, sosyal, kültürel, psikolojik özelliklerinin bütüncül olarak ele alınmadığı ve yer seçimlerinde yerel halkın katılımının sağlanmadığı tespit edilmiştir. Bu durum eski-yeni yerleşim bölgeleri arasında mekânsal bütünleşme sorunlarına neden olmuştur. Yeni inşa edilen çevrelerin eski yaşam alanlarından uzak olması ve yeni sosyal hayatın canlandırılmasındaki güçlükler, yeni yerleşim alanında oluşturulmuş kalıcı konutlarda memnuniyetsizlik oranını artırmıştır. Bu nedenle 
aidiyetlik duygusu kullanıcılarda çoğunlukla oluşmamıştır. Uydukent ve İçmeler TOKİ konutlarında yer değiştirme oranının yüksek olması, İnönü mahallesinde ise mevcut konutların yükseltilerek kullanım yoğunluğunun artırılması bu memnuniyetsizliğe neden olarak gösterilmiştir. Tasarımlar geometrik kurguda yapılmıştır. Yollara cephe veren yapılar genellikle ayrık nizamda, yüksek katlı ve birbirine benzer mimari stillerle oluşturulmuştur. Toplu konutlar yerel mimariden izler taşımamaktadır. Konut tasarımları afetzedelerin eski yerleşim alanlarından bağımsız olarak tasarlanmıştır. $\mathrm{Bu}$ nedenle yeni yerleşim alanlarında aidiyet hissi zayıf kalmıştır. Özellikle yaşı ilerlemiş olanlar kendilerini yeni yerleşim alanına ait hissetmemektedirler. Afet sonrası yerlerinden kopmuş bu insanlar için yer değiştirme sadece fiziksel bir eylem olarak görülmemekte aynı zamanda sosyal ve kültürel yaşamlarından da kopuş olarak değerlendirilmektedir. Konut kullanıcılarının yine büyük çoğunluğu eski yaşamlarına duydukları özlemin sebebini akrabalarla bir arada yaşama, kaynaşma, birlikte zaman geçirebilme, güven duygusu gibi nedenler sıralayarak dile getirmişlerdir. Yeni yerleşimlerde komşuluk ilişkilerinde bu değerleri bulamadıklarını ve bu konudaki memnuniyetsizliklerini vurgulamışlardır (Tablo 5). Sosyal ve kültürel değerler konutların tasarımında, yapımında, kullanımında, arsa kullanım davranışları ve yerleşme açısından mevcut kullanıcılarla beraber gelecek nesilleri de etkilemektedir. Kismen veya tamamen yapılacak her yerleşimde, planlama kriteri olarak eski yerleşimle sosyal ve ekonomik yararları sağlayacak bağlar kurulmalıdır. (Aysan ve Olive, 1987, s.122).

Tablo 5. Sosyal ve kültürel yaşam ölçütleri memnuniyet analizi

\begin{tabular}{|c|c|c|c|c|c|}
\hline \multirow[b]{2}{*}{ Sosyal ve kültürel yaşam } & \multirow{2}{*}{ 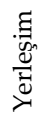 } & \multicolumn{2}{|c|}{ Memnunum } & \multicolumn{2}{|c|}{ Memnun değilim } \\
\hline & & $\mathrm{n}$ & $\%$ & $\mathrm{n}$ & $\%$ \\
\hline \multirow{3}{*}{ Yerleşim kimliği } & A & 32 & 40 & 48 & 60 \\
\hline & B & 28 & 41 & 40 & 59 \\
\hline & $\mathrm{C}$ & 17 & 29 & 42 & 71 \\
\hline \multirow{3}{*}{ Aidiyet duygusu } & $\mathrm{A}$ & 11 & 14 & 69 & 86 \\
\hline & $\mathrm{B}$ & 14 & 17.5 & 54 & 82.5 \\
\hline & $\mathrm{C}$ & 12 & 20 & 47 & 80 \\
\hline \multirow{3}{*}{ Yer ve kültür duygusu } & $\mathrm{A}$ & 22 & 20 & 64 & 80 \\
\hline & $\mathrm{B}$ & 27 & 30 & 41 & 70 \\
\hline & $\mathrm{C}$ & 16 & 27 & 43 & 73 \\
\hline \multirow{3}{*}{ Ortak değerler } & A & 31 & 39 & 49 & 61 \\
\hline & B & 29 & 43 & 39 & 57 \\
\hline & $\mathrm{C}$ & 29 & 49 & 30 & 51 \\
\hline
\end{tabular}




\begin{tabular}{llllll}
\hline & A & 35 & 44 & 45 & 56 \\
Komşuluk ilişkileri ve etkileşim & B & 30 & 44 & 38 & 56 \\
& C & 32 & 54 & 27 & 46 \\
\hline
\end{tabular}

\section{Sosyal Altyap1}

Çalışma alanlarının üçünde de konut yakın çevresinde otopark alanı yeterli büyüklüktedir ancak spor alanları ve yeşil alanlar yeterli donatıya sahip değildir. Üç sitede de görsel yeşil alan ve su öğesi, yeterli sayıda sabit ve hareketli oturma birimleri yer almamaktadır. İnönü ve İçmeler Mahallesi TOKİ konutlarında çöp kutuları yeterli miktarda ve konumda bulunurken, Uydukent toplu konutlarında yetersizdir. Üç konut alanında da yerleşmelerin sınırında, yürüme mesafesinde kreş, okul, manav, market ve cami bulunmaktadır. İnönü Mahallesi ve Uydukent Mahallesi toplu konutları kentin merkezinde bulunduğu için ticaret alanlarına erişim İçmeler Mahallesi toplu konutlarına göre daha kolaydır. Kullanıcı anketleri sonucunda sosyal altyapı ölçütlerinin memnuniyet üzerinde önemli etkiye sahip olduğu tespit edilmiştir (Tablo 6). Görüşme sonucunda bulgular değerlendirildiğinde, yeterli tesislere, hizmetlere ve sosyal donatılara sahip olmayan afetzedelerin çok çeşitli sosyal sorunları dile getirdikleri görülmüştür.

Tablo 6. Sosyal altyapı ölçütleri memnuniyet analizi

\begin{tabular}{|c|c|c|c|c|c|}
\hline \multirow[b]{2}{*}{ Sosyal altyapı } & \multirow{2}{*}{$\frac{\mathscr{D}}{\stackrel{\mathscr{D}}{\mathbb{E}}}$} & \multicolumn{2}{|c|}{ Memnunum } & \multicolumn{2}{|c|}{ Memnun değilim } \\
\hline & & $\mathrm{n}$ & $\%$ & $\mathrm{n}$ & $\%$ \\
\hline \multirow{3}{*}{ Eğitim ve öğretim alanları } & $\mathrm{A}$ & 50 & 62.5 & 30 & 37.5 \\
\hline & $\mathrm{B}$ & 38 & 56 & 30 & 44 \\
\hline & C & 17 & 29 & 42 & 71 \\
\hline \multirow{3}{*}{ Kamu tesisleri } & $\mathrm{A}$ & 38 & 47.5 & 42 & 52.5 \\
\hline & B & 20 & 29 & 48 & 71 \\
\hline & $\mathrm{C}$ & 15 & 25 & 44 & 75 \\
\hline \multirow{3}{*}{ Sosyal alanlar } & $\mathrm{A}$ & 18 & 22.5 & 62 & 77.5 \\
\hline & $\mathrm{B}$ & 7 & 10 & 61 & 90 \\
\hline & $\mathrm{C}$ & 5 & 6 & 54 & 94 \\
\hline \multirow{3}{*}{ Açık alanlar } & A & 50 & 62.5 & 30 & 37.5 \\
\hline & B & 23 & 34 & 45 & 66 \\
\hline & $\mathrm{C}$ & 29 & 49 & 30 & 51 \\
\hline \multirow{3}{*}{ Çocuk etkinlik alanları } & A & 45 & 56 & 35 & 44 \\
\hline & $\mathrm{B}$ & 36 & 44 & 32 & 56 \\
\hline & $\mathrm{C}$ & 30 & 54 & 29 & 46 \\
\hline \multirow{3}{*}{ Depolama, park ve atık hizmetleri } & A & 34 & 42.5 & 46 & 57.5 \\
\hline & $\mathrm{B}$ & 29 & 43 & 39 & 57 \\
\hline & $\mathrm{C}$ & 33 & 41 & 26 & 59 \\
\hline
\end{tabular}




\section{Konut ve Yapılı Çevre Tasarımı}

Üç konut alanında da (İnönü Mahallesi 4+1 konutları dışında) konut-mekân büyüklükleri kullanıcıların büyük çoğunluğu tarafından yeterli bulunmamıştır. Ayrıca ek balkon, kiler, depo, yüklük, misafir odası gibi ek birimlere ihtiyaç duyduklarını belirtmişlerdir. Bodrum katında bulunan ortak sığınaklar depo, kiler olarak kullanılmaktadır. Konut tipleri tercih edilirken bölgenin fiziksel ve sosyal yapısı dikkate alınmamıştır. Geniş aile özelliğine sahip konut kullanıcıları için bu durum memnuniyetsizliğe neden olmaktadır. Kullanıcıların büyük çoğunluğunun müstakil, doğayla iç içe yaşama özlem duydukları görülmüştür. Eski yaşamlarını bu konuda aradıklarını sıkça dile getirmişlerdir. İnönü ve Uydukent TOKİ konut kullanıcıları yakın çevresindeki olanaklara yürüme mesafesiyle erişebilirken, İçmeler TOKİ konut kullanıc1ları bu imkâna sahip değildir (Tablo 7). Fakat bu durumu içmeler TOKİ sakinleri, diğer iki konut bölgesinde yaşayanlara göre gürültü ve koku problemi açısından avantajlı görmektedir. Afet sonrası kalıcı konut kullanıcılarının büyük çoğunluğu ekip biçecek bireysel bahçelerinin olmaması, sakin, gürültüsüz ve sıcak ilişkilerin olduğu bir çevreye sahip olamamaları konusunda memnuniyetsizliklerini dile getirmişlerdir.

Toplu konut projelerinin üçünde de konut tasarımını zenginleştiren renk ve doku öğesi kullanılmamıştır. Konut projeleri esnek tasarlanmamıştır. Toplu konut kullanıcılarının birçoğu yaşadıkları mekânlarda değişiklik yapmak istediğini söylemiştir. Bu değişiklikler odaları büyütmek, ek balkon yapmak, ince işçiliği tamamen yenilemek, depo ve kiler gibi birimler eklemek şeklindedir. Erişilebilirlik ölçütü İnönü ve İçmeler Mahallesi toplu konut projelerinde dikkate alınırken, Uydukent mahallesi toplu konutlarında dikkate alınmamıştır.

Tablo 7. Konut ve yapılı çevre ölçütleri memnuniyet analizi

\begin{tabular}{|c|c|c|c|c|c|}
\hline \multirow[b]{2}{*}{ Konut ve yapılı çevre tasarımı } & \multirow{2}{*}{ 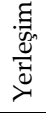 } & \multicolumn{2}{|c|}{ Memnunum } & \multicolumn{2}{|c|}{ Memnun değilim } \\
\hline & & $\mathrm{n}$ & $\%$ & $\mathrm{n}$ & $\%$ \\
\hline \multirow{3}{*}{ Konut türü } & A & 42 & 52.5 & 38 & 47.5 \\
\hline & $\mathrm{B}$ & 26 & 38 & 42 & 62 \\
\hline & $\mathrm{C}$ & 10 & 17 & 49 & 83 \\
\hline \multirow{3}{*}{ Konut büyüklüğü } & A & 31 & 39 & 49 & 61 \\
\hline & B & 24 & 35 & 44 & 65 \\
\hline & $\mathrm{C}$ & 14 & 24 & 45 & 76 \\
\hline \multirow{3}{*}{ Konut esnekliği } & A & 10 & 12.5 & 70 & 87.5 \\
\hline & B & 0 & 0 & 68 & 100 \\
\hline & C & 2 & 3 & 57 & 97 \\
\hline
\end{tabular}




\begin{tabular}{lccccc}
\hline & A & 34 & 42.5 & 46 & 57.5 \\
Altyapı ve hizmetler & B & 32 & 47 & 36 & 53 \\
& C & 15 & 25 & 44 & 75 \\
\hline \multirow{2}{*}{ Erişilebilirlik } & A & 70 & 87.5 & 10 & 12.5 \\
& B & 20 & 29 & 48 & 71 \\
Konut mahalle ilişkisi & C & 31 & 53 & 28 & 47 \\
\hline
\end{tabular}

\section{Güvenlik}

Literatürde konut tercihi konusu araştırıldığında en önemli ölçütlerden biri sosyal sürdürülebilirliğin de temel ölçütü olan "güvenlik" (Roitman, 2010, s. 34; Blandy ve Lister, 2005, s. 292) olarak karşımıza çıkmaktadır. İnsanlar öncelikle yaşadıkları çevrede kendilerini güvende hissetmek istemektedirler. Bu çalışmada da "Güvende olma" konusu kullanıcı memnuniyetini en çok etkileyen kriter olarak dile getirilmiştir. Can ve mal güvenliği açısından İnönü ve İçmeler Mahallesi toplu konut kullanıcıları bir sorunun olmadığını dile getirirken Uydukent Mahallesi toplu konut kullanıcıları büyük çoğunluğu konut güvenliğinin yeterince sağlanmadığını düşünmektedir.

İnönü Mahallesi TOKİ konutlarında gece kullanımı için yeterli aydınlatma elemanı kullanılırken diğer iki konut alanında aydınlatma yetersiz bulunmuştur. Konut bölgelerinde güvenlik amaçlı alınan önlemler arasında duvarlarla alanın sınırlandırılması, belirli noktadan kontrollü giriş-çıkışın yapılması bulunmaktadır. İnönü TOKİ konutlarının bazılarında kapalı devre kamera sistemi bulunmaktadır. Kullanıcıların çoğu mahremiyetin sağlandığını düşünmektedir. Üç toplu konut bölgesinde de yaşayan kullanıcıların çoğunluğu bu konutlarda depreme karşı kendilerini güvende hissettiklerini ancak yangına karşı güvende hissetmediklerini dile getirmişlerdir (Tablo 8). Bunun nedeni depremden hemen sonra inşa edilen bu konutlara yapım sistemi aç1sından güvenmeleri ancak yangınlara karşı yeterince önlemin alınmadığını düşünmeleridir. Yine bu bölgelerde yaşayan konut kullanıcılarının çoğunluğu çocuk oyun ve spor alanlarının düzenli bakımının yapılmadığından şikâyetçi olup, konut çevresinde bilgilendirme yönlendirmelerin çok yetersiz olduğunu söylemişlerdir. 
Tablo 8. Güvenlik ölçütleri memnuniyet analizi

\begin{tabular}{|c|c|c|c|c|c|}
\hline \multirow[b]{2}{*}{ Güvenlik } & \multirow{2}{*}{ 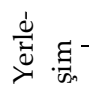 } & \multicolumn{2}{|c|}{ Sağlanmış } & \multicolumn{2}{|c|}{ Sağlanmamış } \\
\hline & & $\mathrm{n}$ & $\%$ & $\mathrm{n}$ & $\%$ \\
\hline \multirow{3}{*}{ Can ve mal güvenliği } & A & 51 & 64 & 29 & 36 \\
\hline & B & 23 & 34 & 45 & 66 \\
\hline & C & 45 & 76 & 14 & 24 \\
\hline \multirow{3}{*}{ Deprem güvenliği } & $\mathrm{A}$ & 64 & 80 & 16 & 20 \\
\hline & $\mathrm{B}$ & 42 & 62 & 26 & 38 \\
\hline & C & 46 & 78 & 13 & 22 \\
\hline \multirow{3}{*}{ Mahremiyet } & $\mathrm{A}$ & 65 & 20 & 15 & 80 \\
\hline & B & 43 & 30 & 25 & 70 \\
\hline & C & 40 & 27 & 19 & 73 \\
\hline \multirow{3}{*}{ Oyun alanları bakımlı ve güvenli } & $\mathrm{A}$ & 38 & 47.5 & 42 & 52.5 \\
\hline & $\mathrm{B}$ & 13 & 16 & 55 & 84 \\
\hline & C & 15 & 25 & 44 & 75 \\
\hline \multirow{3}{*}{ Yangın güvenliği } & $\mathrm{A}$ & 12 & 15 & 68 & 85 \\
\hline & B & 6 & 9 & 62 & 91 \\
\hline & C & 10 & 17 & 49 & 83 \\
\hline \multirow{3}{*}{ Yönlendirme ve bilgilendirme } & $\mathrm{A}$ & 15 & 19 & 45 & 81 \\
\hline & $\mathrm{B}$ & 0 & 0 & 68 & 100 \\
\hline & C & 0 & 0 & 59 & 100 \\
\hline
\end{tabular}

\section{Sağlık, Yaşam Kalitesi ve İyileşme}

Afet kullanıcılarının birçoğu 2003 depremi sonrası yapılan afet konutlarının fiziksel anlamda eski konutlarına göre yenilendiğini ve depreme dayanıklılığının sağlandığına inandıklarını vurgulamışlardır. Bu konuda yaşam şartlarının eski yerleşim bölgelerine göre iyileştiğine inanmaktadırlar. Ancak konut alanlarında sosyal sürdürülebilirliğin sağlanması adına afetzedelerin önceki yaşantılarıyla bağ kurabilecekleri sosyal alt yapı ve tesisler, aidiyeti destekleyecek ortak mekânlar dikkate alınmamıştır. Fiziksel çevreyle birlikte psikolojik, sosyal ve ekonomik bütünlüğü bozulmuş afetzedelere ihtiyaçlarına cevap veren yeni yerleşim alanları kazandırmak deprem sonrası en büyük sorunlardan biridir. (Taş, Coşkun ve Taş, 2007, s. 3422). Yakın mesafede sağlık ocağı, özel hastane ve eczanelerin bulunması olumlu karşılanmaktadır.

\section{Tartışma ve Sonuç}

2003 Bingöl depremi sonrası kentin farklı bölgelerinde oluşturulan kalıcı deprem konut kullanıcıları ile yapılan görüşmeler ve anketler sonucunda, toplu konut uygulamalarının sosyal ve kültürel yaşam üzerindeki etkileri sosyal sürdürülebilirlik parametreleri dikkate alınarak tespit edilmiştir. Buradaki 
ana hedef demografik yapı-sosyal sürdürülebilirlik ve sosyal sürdürülebilirlik-kullanıc memnuniyeti ilişkisini nicel ve nitel yöntemleri birlikte kullanarak ölçmektir. Bu bağlamda, kalıcı konut kullanıcılarına cinsiyet, yaş, eğitim ve gelir durumları, mülk durumları, kullanım süreleri, yer değiştirme durumları ile ilgili genel sorular yöneltilmiştir. Farklı kullanıcı tiplerine göre farklı niteliklerde konut üretmek, kullanıcı gereksinimlerinin karşılanabilmesi açısından oldukça önemlidir. Bu nedenle afet sonrası barınma aşamalarında sosyal araştırmalar ve çeşitli anketler yapılmalı, kullanıcı katılımıyla konut özellikleri belirlenmeli ve üretilmelidir. Tasarlanmış olan birkaç tip projeyi her afet bölgesinde uygulamak yerine, yöreye özgü çözümler üretilmeli ve konutların dolayısıyla da kullanıcıların yerel koşullara adaptasyonu sağlanmalıdır.

Alan çalışmasında depremzedelerin sosyal sürdürülebilirlik ana kriterleri ve alt kriterlerine ilişkin yaş, gelir düzeyi, yer değiştirme, ev sahipliği ve kentte yaşam süresi arasında anlamlı ilişkiler belirlenmiştir. Özellikle kırsal alanlardan getirilerek kent merkezindeki kalıcı deprem konutlarına yerleştirilen afetzedelerde aidiyet, yer ve kültür duygusu ve ortak değerler kriterleri anlamlı düzeyde oluşmamıştır. Merkezde bulunan İnönü Mahallesi kalıcı konut kullanıcıları; konutlarının aynı yerde yapılması nedeniyle aidiyetlik duygusu diğer iki bölgeye göre daha fazla oluşmuş̧tur. Ancak bu bölgedeki konut kullanıcıları da daha önce sahip oldukları müstakil konut düzeninden toplu konut düzenine geçmelerinden dolayı komşuluk ilişkileri kriterinde memnuniyetsizlik dile getirmişlerdir. Kalıcı afet konutlarında sosyal donatı çeşitliliğinin anlamlı düzeyde memnuniyeti etkilediği görülmüş̧ür. Deprem sonrası yeni yerleşimler oluşturulurken konut tipi, büyüklüğü, esnekliği, sosyal altyapı ve donatılar gibi konulara kullanıcıların tasarım aşamasından itibaren dahil edilebilmesinin kullanıcı memnuniyetinde önemli düzeyde etkisi olduğu tespit edilmiştir. Yine yapılan alan çalışmasında güvenlik ve yaşam şartlarının iyileşmesi konularının kalıcı konut kullanıcı memnuniyeti üzerinde önemli etkisi olduğu tespit edilmiştir.

Çalışma sonuçlarının genel değerlendirmesi yapıldığında;

- Yapılan çalışma ile "afet sonrası kalıcı konut üretiminde sosyal sürdürülebilirlik parametrelerinin dikkate alınması kullanıcı memnuniyetinde önemli role sahiptir" hipotezi doğrulanmıştır.

-Türkiye'de meydana gelen depremler sonrasında yeniden inşa süreci, teknik bir süreç olarak görülmekte ve bu nedenle yeni yerleşim alanları oluşturulurken fiziksel boyut üzerinde odaklanılmaktadır. Ancak yapılan araş- 
tırma sonucu; afet sonrası yeni yerleşim alanlarında sosyal, kültürel ve psikolojik ihtiyaçları dikkate alan uygulamaların, kullanıcı memnuniyeti üzerinde daha etkili olduğu görülmektedir.

-Kalıcı afet konutları uygulamalarında, memnuniyetin sağlanması için kullanıcı katılımı, tasarım kararlarından itibaren tüm süreçlere dahil edilmelidir. Bu sonuç Coburn ve Spence (2002)'in "Yer seçimi afetzedelerle birlikte, alanın ve konutların tasarımı afetzedelerin istek ve ihtiyaçları doğrultusunda yapılmalıdır" değerlendirmesi ve Kürüm Varolgüneş (2020)'in "Konutun hazır olarak insanlara sunulması yerine, kullanıcıların kendi çözümlerini üretmek üzere organize edildiği (kullanıcı katılımı sağlanan) yerleşimlerin oluşturulması uzun süreli memnuniyeti sağlayacaktır" bilgisiyle örtüşmektedir.

-Kalıc konut kullanıcıları; yeni yerleşim alanları oluşturulurken eski yaşam alışkanlıkları ve kültürel değerlerin tasarımlara ve uygulamalara yansıtılmasının memnuniyetlerini büyük ölçüde etkileyeceğini dile getirmişlerdir. Bu sonuç Aysan ve Olive (1987)'in yaptıkları çalışmada belirttiği “kısmen veya tamamen yapılacak her yerleşimde, planlama kriteri olarak eski yerleşimle sosyal ve ekonomik yararları sağlayacak bağlar kurulmalıdır" ve "toplulukların yaşam biçimlerini, gelenek ve göreneklerini, kültürlerini, fiziksel, ekonomik, sosyal yapılarını, psikolojilerini koruyacak ve gelecek nesillere aktaracak araçlardan birisi sosyal sürdürülebilirlik olarak karşımıza çıkmaktadır" bilgilerini desteklemektedir.

-Afet sonrası yapılan kalıcı konut projelerinde sosyal donatılarla ilgili sunulacak çeşitlilik farklı grupları aynı ortamda bir araya getirerek sosyal yaşamın gelişmesini sağlayacak ve konut kullanıcılarının aidiyet duygusunu geliştirecektir. Bu sonuç Holden (2012)' nın 'sosyal sürdürülebilirlik; uyumlu sosyal ilişkileri sağlayan, sosyal bütünleşmeyi geliştiren ve tüm toplum için yaşam koşullarını iyileştiren bir kentsel gelişim sürecidir" tanımını desteklemektedir.

-Afet konutlarının bulunduğu alan ve yakın çevresiyle ilişki kurabilmesi çok önemlidir. Üretilen kalıcı konutlar mevcut kimliğin korunmasını ya da yeni yapay çevreler oluşturuluyorsa olumlu yönde kimlik katması memnuniyet düzeyini önemli ölçüde etkileyecektir.

-Sosyal yönden sürdürülebilir bir toplumdan ve kullanıcı memnuniyetinden söz edilebilmesi için cinsiyet, yaş, gelir düzeyi ayrımı yapılmadan, sosyal ihtiyaç ve donatıların adil ve kapsayıcı bir şekilde hizmete sunulması gereklidir. 
- Konutlar ve yapılı çevrede; mahremiyet, sosyal iletişim, özgürlük, seçim ve özerklik gibi özellikler kazandırılması yine kullanıc memnuniyetini sağlayan önemli etkenlerdir.

Özetle; konutun sosyal, kültürel yapılarla ve bölgesel özelliklerle uyumu, yeniden yapılanmada yerleşimin benimsenmesi, aidiyet duygusu, ortak değerlerin pekişmesi, güven hissi, kimlik, yaşam kalitesinde iyileşme gibi kazanımlar için dikkat edilmesi gereken konulardır 


\title{
Extended Abstract
}

\section{Evaluation of Social Sustainability Performance in Post-disaster Permanent Housing: Case of Bingöl}

\author{
Fatma Kürüm Varolgüneş \\ ORCID: 0000-0002-3214-4274
}

Social sustainability is one of the tools that will protect the lifestyles, traditions and customs, cultures, physical, economic, social structures, and psychologies of communities and carry them to future generations. The settlements, which have been reconstructed due to the demolitions occurring after the earthquake experienced, should be applied according to the parameters and criteria of the social sustainability concept, which is very contemporary in the literature and remains passive in practice. Still, in the applications in permanent residences and settlements after the earthquake, studies that highlight the physical structure and de-emphasize the social system are carried out.

When permanent residential settlements designed after an earthquake do not meet the needs of people, they can create situations that are not adopted, owned by communities or that cause that community to assume a separate identity. When we look at the parameters and criteria that should be applied to ensure social sustainability while establishing the settlements, it is necessary to provide social infrastructure and facilities that existed in the previous lives of the communities, to build common spaces and structures that will nurture and support local identity and belonging, to create accessible social and cultural facilities, to support the local economy, to create a mechanism with participants from all segments, to provide housing, infrastructure and services that keep up with the era with a flexible planning approach, and to produce decentralized local solutions, to create the diversity that will appeal 
to all segments of the society and meet the demands, to encourage organizations that support the community, to increase areas to be inherited to future generations, and to implement practices that will help the society's economy.

In this context, in this study, as a result of the interviews and surveys conducted with the residents of the permanent earthquake buildings created in different parts of the city after the 2003 Bingöl earthquake, the effects of mass housing implementations on social and cultural life were determined by considering the social sustainability parameters. The main goal here is to estimate the relationship between socio-demographic structure, social sustainability and user satisfaction by using a qualitative method. Therefore, general questions were asked to permanent residents regarding their gender, age, education and income status, property status, duration of use, and displacement. Also, answers were sought for the questions of how the settlements should be designed to ensure social sustainability in permanent housing settlements after the earthquake, what is the equivalent of social sustainability in the literature, and what the design policies to be implemented to ensure social sustainability are.

Within the scope of the study, observation, questionnaire and interview technique were used to obtain the data. In the survey study, the users were asked to evaluate the house and the environment they lived in, together with socio-demographic information. The hypothesis examined within the scope of the study is as follows:

Hypothesis 1: Considering social sustainability parameters in the production of permanent housing after a disaster has a vital role in user satisfaction.

In line with this hypothesis, the expectation and satisfaction levels of disaster victims with different socio-demographic structures about permanent disaster residences were revealed by scanning the literature and investigated by associating them with social sustainability parameters. Before starting the field study, the research population was determined, and the data were obtained with a qualitative and quantitative method with the clarification of the sample. In the findings section, the data were analyzed and interpreted. The noticeable results of the study carried out in three permanent housing areas produced after the earthquakes can be listed as follows:

- It is observed that practices that consider social, cultural and psychological requirements in new settlements after the disaster are more effective on user satisfaction. 
- In permanent disaster housing applications, user participation should be included in all processes starting from design decisions in order to ensure satisfaction.

- Permanent residence users stated that reflection of their old living habits and cultural values on the designs and applications while creating new residential areas would significantly influence their satisfaction.

- The diversity that will be provided regarding social facilities in permanent housing projects after the disaster will bring diverse groups together in the same environment, which will ensure the development of social life and develop the sense of belonging of residential users.

- It is crucial for disaster houses to be able to establish a relationship with the area they are located and their immediate surroundings. If the houses produced preserve the existing identity or create new artificial environments, their positive contribution to identity will significantly affect the satisfaction level.

- Social needs and equipment should be provided fairly and inclusively, regardless of gender, age, income level to achieve a socially sustainable society and user satisfaction.

- Providing features such as privacy, social communication, freedom, choice and autonomy for the residences and built environment is also essential for ensuring user satisfaction.

In summary, the harmony of the residence with the social, cultural structures and regional characteristics, the adoption of the settlement in the reconstruction, the sense of belonging, the consolidation of shared values, the feeling of trust, identity, and the improvement in the quality of life are issues that need to be considered.

\section{Kaynakça/References}

Afet ve Acil Durum Yönetim Başkanlığı [AFAD] (2019). Türkiye'deki Depremler, Afet ve Acil Durum Yönetim Başkanlı̆g. 17 Eylül 2019 tarihinde https://www.afad.gov.tr/ adresinden erişildi.

Akadiri, P.O., Chinyio, E.A. ve Olomolaiye, P.O. (2012). Design of a sustainable building: A conceptual framework for implementing sustainability in the building sector. Buildings 2, 126-152.

Aysan, Y. ve Oliver, P. (1987). Housing and Culture after Earthquakes: A guide for future policy making on housing in seismic areas, Oxford: Oxford polytechnic.

Blandy, S. ve Lister, D. (2005). Gated communities:(ne) gating community development? Housing studies, 20, 287-301. 
Carrasco, S., Ochiai, C. ve Okazaki, K. (2017) Residential satisfaction and housing modifications. International Journal of Disaster Resilience in the Built Environment, 8(2), 175-189.

Coburn, A. ve Spence, R. (2002). Earthquake protection, Chichester: John Wiley \& Sons.

Colantonio, A. ve Dixon, T. (2011). Urban regeneration and social sustainability: Best practice from European cities: John Wiley \& Sons.

Franscescato, G., Wiedemann, S. ve Anderson, J. R. (1987). Residential Satisfaction. In W. van Vliet vd. (Eds.), Housing and neighbourhoods. Theoretical and empirical contributions, 43-58. New York/London: Greenwood Press.

Gomaa, B. ve Sakr, N. (2015). Social Sustainability; Maintenance of Socio-Cultural Characteristics: A Case Study of El-Raml Station. European Journal of Sustainable Development, 4, 203-303.

Hayles, C.S. (2010). An examination of decision making in post disaster housing reconstruction. International Journal of Disaster Resilience in the Built Environment, 1, 103-122.

Holden, M. (2012). Urban policy engagement with social sustainability in metro Vancouver. Urban Studies, 49, 527-542.

Hutchins, M.J. ve Sutherland, J.W. (2008). An exploration of measures of social sustainability and their application to supply chain decisions. Journal of Cleaner Production, 16, 1688-1698.

Ingirige, B., Jones, K. ve Keraminiyage K. (2013). Achieving success in post-disaster resettlement programmes through better coordination between spatial and socio-economic/cultural factors. International Journal of Disaster Resilience in the Built Environment, 4, 352-372.

Jamshed, A. Rana I.A. ve McMillan J.M. (2019). Building community resilience in post-disaster resettlement in Pakistan. International Journal of Disaster Resilience in the Built Environment, 10 (4), 301-315.

Johnson, C. (2007). Impacts of prefabricated temporary housing after disasters: 1999 earthquakes in Turkey. Habitat international, 31, 36-52.

Juan, Y.K., Hsing, N.P. ve Hsu Y.H. (2019). Applying the Kano two-dimensional model and quality function deployment to develop sustainable planning strategies for public housing in Taiwan. Journal of Housing and the Built Environment, 34, 265-282.

Kalafat, D., Güneş, Y. ve Arpat E. (2003). May 1, 2003 Bingöl earthquake. In: Institute KOaER (ed). İstanbul: Boğaziçi University.

Kowaltowski, D.C., Muianga, E.A.D. ve Granja, A.D. (2019). A critical analysis of research of a mass-housing programme. Building Research E Information, 47, 716-733.

Kürüm Varolgüneş, F. (2020). Evaluation of vernacular and new housing indoor comfort conditions in cold climate -a field survey in eastern Turkey, International Journal of Housing Markets and Analysis, 13 (2), 207-226. 
Kürüm Varolgüneş F. (2020). Post-disaster permanent housing: the case of the 2003 Bingöl earthquake in Turkey. Disaster Prevention and Management.

Kürüm Varolgüneş F. (2021). Success factors for post-disaster permanent housing: example of Turkish Earthquakes. The Turkish Online Journal of Design Art and Communication, 11 (1), 115-130.

Littig, B. ve Griessler, E. (2005). Social sustainability: a catchword between political pragmatism and social theory. International journal of sustainable development, 8, 65-79.

Missimer, M. Robèrt, K.H. ve Broman, G. (2017). A strategic approach to social sustainability-Part 2: a principle-based definition. Journal of Cleaner Production, 140, 42-52.

Moldan, B., Janoušková, S. ve Hák, T. (2012). How to understand and measure environmental sustainability: Indicators and targets. Ecological Indicators, 17, 4-13.

Ortiz, O., Castells, F. ve Sonnemann, G., (2009). Sustainability in the construction industry: A review of recent developments based on LCA. Construction and building materials, 23, 28-39.

Rapoport, A. (1977). Human aspects of urban form: towards a man-environment approach to urban form and design, Elsevier:Oxford.

Roitman, S. (2010). Gated communities: definitions, causes and consequences. Proceedings of the Institution of Civil Engineers.Urban Design and Planning, 163, 31-38.

Sachs, I. (1999). Social sustainability and whole development: exploring the dimension of Sustainable Development in E. Becker and Th. Jahn (Eds) Sustainability and the Social Sciences. UNESCO \& ISOE:New York.

Shirazi, M.R. ve Keivani, R. (2019). The triad of social sustainability: Defining and measuring social sustainability of urban neighbourhoods. Urban Research $\mathcal{E}$ Practice, 12, 448-471.

Singhaputtangkul, N., Low, S.P. ve Teo, A.L. (2013). Knowledge-based decision support system quality function deployment (KBDSS-QFD) tool for assessment of building envelopes. Automation in Construction, 35, 314-328.

Speare, A. (1974). Residential satisfaction as an intervening variable in residential mobility. Demography, 11, 173-188.

Tas, N., Cosgun, N. ve Tas, M. (2007). A qualitative evaluation of the after earthquake permanent housings in Turkey in terms of user satisfaction-Kocaeli, Gundogdu Permanent Housing model. Building and Environment 42, 34183431.

Todd, J.A., Crawley, D. ve Geissler, S. (2001). Comparative assessment of environmental performance tools and the role of the Green Building Challenge. Building Research \& Information, 29, 324-335.

Vallance, S., Perkins, H.C. ve Dixon, J.E. (2011). What is social sustainability? A clarification of concepts. Geoforum, 42, 342-348. 
WCDE. (1987). Report of the World Commission on Environment and Development: Our common future. $10 \quad$ Şubat 2018 tarihinde https://www.sustainabledevelopment.un.org/ adresinden erişildi.

Weingaertner, C. ve Moberg, Å. (2014). Exploring social sustainability: Learning from perspectives on urban development and companies and products. Sustainable Development, 22, 122-133.

Williams, K. ve Dair, C. (2007). What is stopping sustainable building in England? Barriers experienced by stakeholders in delivering sustainable developments. Sustainable development, 15, 135-147.

Woodcraft, S. (2015). Understanding and measuring social sustainability. Journal of Urban Regeneration \& Renewal, 8, 133-144.

Woodcraft, S. ve Dixon, T. (2013). Creating strong communities-measuring social sustainability in new housing development. Town and Country Planning Association, 82, 473-480.

Zimmermann, M., Althaus H.J. ve Haas, A. (2005). Benchmarks for sustainable construction: A contribution to develop a standard. Energy and Buildings, 37, 1147-1157. 